\title{
ESTIMATES OF MARGINS IN ASME CODE STRENGTH VALUES FOR STAINLESS STEEL NUCLEAR PIPING ${ }^{1}$
}

\author{
Arthur G. Ware \\ Idaho National Engineering Laboratory \\ Lockheed Idaho Technologies Company \\ Idaho Falls, Idaho
}

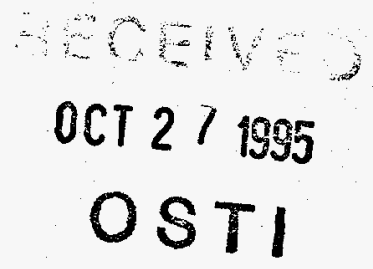

\section{ABSTRACT}

The margins in the ASME Code stainless steel allowable stress values that can be attributed to the variations in material strength are evaluated for nuclear piping steels. Best-fit curves were calculated for the material test data that were used to determine allowable stress values for stainless steels in the ASME Code, supplemented by more recent data, to estimate the mean stresses. The mean yield stresses (on which the stainless steel $\mathrm{S}_{\mathrm{m}}$ values are based) from the test data are about 15 to $20 \%$ greater than the ASME Code yield stress values. The ASME Code yield stress values are estimated to approximately coincide with the $97 \%$ confidence limit from the test data. The mean and $97 \%$ confidence limit values can be used in probabilistic risk assessments of nuclear piping.

\section{INTRODUCTION}

Recent studies of piping system seismic design of nuclear piping have evaluated the margins of safety inherent in ASME Code Section III methodology (Antaki, 1993, Adams and Stevenson, 1992.) These margin studies were focused on the failure theories for ductile metal, and the results of tests of piping sections under dynamic loads.

Section III of the ASME Code (ASME, 1992) applies factors of safety against incipient yielding or rupture of test specimens loaded in simple tension. The allowable stress values (designed as $\mathrm{S}_{\mathrm{m}}$ in the ASME Code) are based on the minimum strength properties of metals. Therefore, another margin of safety in the allowable stress values is the estimate of the material strengths. This paper estimates the margins between

1. Work supported by the U.S. Nuclear Regulatory Commission, Office of Nuclear Regulatory Research, under DOE Contract No. DE-AC07-94ID13223. best-fit curves for stainless steel material strengths from available test data, and the values used in the ASME Code to determine the allowable stresses.

\section{TEST DATA}

The allowable $S_{m}$ values for stainless steel in the ASME Code are based on two-thirds of the yield stress at room temperature for temperatures up to $300^{\circ} \mathrm{F}$, and nine-tenths of the yield strength at temperature for temperatures from 300 to $650^{\circ} \mathrm{F}$. Room temperature to $650^{\circ} \mathrm{F}$ represents the range of temperatures typically used in the analysis of nuclear power plants.

Data for three stainless steels commonly used in nuclear power plant piping construction were collected from available sources. The stainless steels evaluated were wrought Type 304 , cast Type 304 , and Type 316.

\section{Wrought Type 304 pipe}

The oldest Type 304 stainless steel data sets are from Simmons and Cross (1952). This ASTM special publication had two supplements (Simmons and Van Echo, 1965; Smith, 1969). The 1952 data series contains values for three forms of 18-8 steel (although Type 304 stainless steel is not specifically referred to in this reference, its composition is $18 \mathrm{Cr}-8 \mathrm{Ni}$ ): bar stock, sheet, and other (cast). There is no specific mention of the wrought pipe/tube product form. Supplement 1, published in 1965, specifically lists wrought Type 304 stainless steel as a separate product form, whereas Supplement 2, published in 1969 , lists Type $304-304 \mathrm{H}$ pipe/tube as a separate product form. Other sources of data are Hays et al. (1986), Hiser (1989), Kanninnen (1982), Wilkowski et al. (1989), and Yagawa et al. (1984).

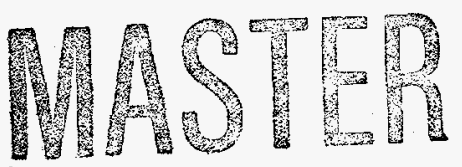




\section{Cast Type 304 pipe}

Most of the data in the ASTM reports (Simmons and Cross, 1952; Simmons and Van Echo, 1965; Smith, 1969) are for wrought stainless steel. The 1969 report excludes data for cast stainless steels, whereas the 1952 and 1965 reports contain only a few data points for cast material at several temperatures. The data in the 1965 report are for cast stainless steel pipes that had been bored and cold expanded. Other data sources are Hiser (1988) and Chopra et al. (1991).

\section{Type 316}

There are less available data for Type 316 stainless steel than for Type 304 stainless steel. A comparison of the wrought and cast properties of Type 304 stainless steel pipe shows that the cast yield stress and ultimate tensile strength values are less than the wrought values by about 5 and $3 \%$, respectively. From plots of the corresponding values for Type 316 stainless steel, it appears that there also is not a great difference between the wrought and cast values; therefore, no differentiation will be made between these two Type 316 stainless steels.

The Type 316 stainless steel data are from Simmons and Van Echo (1965), Smith (1969), and CF8M (the cast form of Type 316 stainless steel) from Bamford and Swamy (1984), Chopra et al. (1991), Hiser (1988), Wilkowski et al. (1989), and Wilkowski (1984).

\section{YIELD STRESS}

Plots of the data for the three stainless steels are shown in Figures 1 through 3 . Several types of curve fits were used to approximate the data. A cubic polynomial appeared to give a good representation. The equation of the curve fit, with $y$ representing the yield stress and $x$ representing the temperature, are shown on the graphs. The ASME Code yield stress values for SA-376 Type 304 pipe, SA-451 CPF3/CPF8 (cast Type 304) pipe, and SA-451 CPF3M/CPF8M Type 316 stainless steels are also included on the graphs. The ASME Code values are an approximate lower bound to the data. There are two test data values that are less than $30 \mathrm{ksi}$ at $70^{\circ} \mathrm{F}$ (one data point each on Figure 1 and Figure 2), but since the minimum yield stress for these materials is $30 \mathrm{ksi}$, pipe from these two material lots would not be used in nuclear plant construction. Stainless steel does not have a distinct yield point, and common practice is to use $0.2 \%$ permanent set (as determined from the test) for the yield strength value. The lack of a distinct yield point may contribute to some of the scatter in the data.

The best-fit values and the ASME Code values were used to calculate the stress differences between the ASME Code minimum yield stress values and the best-fit yield stresses at the corresponding temperatures. Plots of these stress differences are shown in Figures 4 through 6 . The minimum stress difference for wrought Type 304 stainless steel pipe is about $3.4 \mathrm{ksi}$ at $450^{\circ} \mathrm{F}$ (Figure 4). The minimum stress difference for cast Type 304 stainless steel pipe is about 3.8 ksi at $650^{\circ} \mathrm{F}$. The minimum stress difference for Type 316 stainless steel pipe is about $3.8 \mathrm{ksi}$ at $650^{\circ} \mathrm{F}$.

The curve-fit yield stress was divided by the ASME Code yield stress value at the corresponding temperature. Subtracting 1 from these values results in a fraction that represents the increase (that is, the margin) in the best-fit curve values over the ASME Code values. These increases are shown in Figures 7 through 9. The minimum margin for wrought Type 304 stainless steel pipe is about $17 \%$ at $425^{\circ} \mathrm{F}$. The minimum margin for cast Type 304 stainless steel pipe is about $18 \%$ at $100^{\circ} \mathrm{F}$. The minimum margin for Type 316 stainless steel pipe is about $20 \%$ at $550^{\circ} \mathrm{F}$.

There are too few data points available to determine a probability distribution for the stress values. Figure 10 shows a histogram of the yield stress values for all three stainiess steels at $70^{\circ} \mathrm{F}$. The distribution could be assumed to be constant between 30 and $44 \mathrm{ksi}$, or a normal or lognormal distribution truncated at a lower bound of $30 \mathrm{ksi}$. However, for purposes of estimating the confidence level that the ASME Code yield stress values have with respect to the data, a normal distribution was assumed. The data from all three stainless steels are plotted together in Figure 11, along with the ASME Code yield stress values for wrought Type 304 stainless steel. Also included is the $97 \%$ lower confidence level based on an assumed normal distribution of the test data from 70 to $550^{\circ} \mathrm{F}$. As seen in Figure 11, the 97\% lower confidence curve closely approximates the ASME Code values. Thus we can conclude that the ASME Code values represent a high confidence level, say 95 to $99 \%$, that the ASME Code values are less than the test data. For probability studies, the yield stress value on the best-fit curve could be used as the mean of the yield stress distribution for a give temperature, and the ASME Code value could be used as the $97 \%$ lower confidence limit.

\section{ULTIMATE TENSILE STRENGTH}

Although the ultimate tensile strength values are not used in the ASME Code to compute $S_{\mathrm{m}}$ values for stainless steel, the test data are presented here for interest. The data for the three stainless steels are shown in Figures 12 through 14. The ASME values for a minimum ultimate tensile strength of 70 $\mathrm{ksi}$ are included. (The ASME Code also lists $75 \mathrm{ksi}$ minimum ultimate tensile strength material.) Third-order polynomial curves fits were used for the Type 304 stainless steels, and a fourth-order polynomial fit was used for Type 316 stainless steel. The ASME Code values and the curve fits appear relatively closer together than do the corresponding curves for the yield stresses in Figures 1 through 3. In fact, several data points are below the ASME Code ultimate tensile strength values. 


\section{DISCLAIMER}

This report was prepared as an account of work sponsored by an agency of the United States Government. Neither the United States Government nor any agency thereof, nor any of their employees, makes any warranty, express or implied, or assumes any legal liability or responsibility for the accuracy, completeness, or usefulness of any information, apparatus, product, or process disclosed, or represents that its use would not infringe privately owned rights. Reference herein to any specific commercial product, process, or service by trade name, trademark manufacturer, of otherwise does not necessarify constitute or imply its endorsement, recommendation, or favoring by the United States Government or any agency thereof. The views and opinions of authors expressed herein do not necessarily state or reflect those of the United States Governmeat or any agency thereof. 


\section{DISCLAIMER}

Portions of this document may be illegible in electronic image products. Images are produced from the best available original document. 


\section{CONCLUSIONS}

The material test data used as the basis for the ASME Code Section III allowable stress values, supplemented by more recent test data, are evaluated to estimate the differences in the ASME Code allowable stress values and best-fit values to the data. The ASME Code allowable stress values $\left(\mathrm{S}_{\mathrm{m}}\right)$ are based on the yield stress. The best-fits to the yield stress data are about $20 \%$ greater than the ASME Code yield stress values at corresponding temperatures. Assuming that the yield stress data are distributed normally about the mean, it is estimated that the ASME Code yield stress represents a high (approximately 97\%) confidence level to the test data. The margins between the ASME Code ultimate tensile strength values and the test data appear to be less than for the yield stress data; however, these values are not used to determine allowable stress values for stainless steels (the stainless steel $\mathrm{S}_{\mathrm{m}} \mathrm{s}$ are based on the yield stresses).

\section{REFERENCES}

Adams, T. M., and J. D. Stevenson, 1992, "Margins of Safety Associated with Seismic Design of Piping", Proceedings of the Fourth Symposium on Current Issues Related to Nuclear Power Plant Structures, Equipment, and Piping, Orlando, FL, IV/5.

Antaki, G. A., 1993, "Failure and Factors of Safety in Piping System Design," Piping, Supports, and Structural Dynamics, ASME PVP 264, pp. 59-64.

American Society of Mechanical Engineers, 1992, Boiler and Pressure Vessel Code, Section II (Materials), Part D Properties.

Bamford, W. H., and S. A. Swamy, 1984, "The Case for Eliminating Instantaneous Pipe Break as a Design Basis for Westinghouse Main Coolant Piping," Proceedings of the CSNI Specialist Meeting on Leak-Before-Break in Nuclear Reactor Piping, NUREG/CR-0051, pp. 56-125.

Chopra, O. K., et al., 1991, Long-Term Embrittlement of Cast Duplex Stainless Steels in LWR Systems, NUREG/CR-4744, Volume 4, Number 2.

Hays, R. A., et al., 1986, Fracture Analysis of Welded Type 304 Stainless Steel Pipe, NUREG/CR-4538, Volume 1.

Hiser, A. L., 1988, Fracture Toughness Characterization of Nuclear Piping Steels, NUREG/CR-4538, Volume 1.
Hiser, A. L., 1989, Fracture Toughness Characterization of Thermally Aged Stainless Steels, NUREG/CR-5188.

Kanninnen, M. F., et al., 1982, Instability Predictions for Circumferentially Cracked Type 304 Stainless Steel Piping Under Dynamic Loads, EPRI NP-2347. Electric Power Research Institute, Palo Alto.

Simmons, W. F., and H. C. Cross, 1952, ElevatedTemperature Properties of Stainless Steels, ASTM Special Publication No. 124.

Simmons, W. F. and J. A. Van Echo, 1965, Report on the Elevated-Temperature Properties of Stainless Steels, ASTM Data Series Publication DS 5-S1 (Supplement to Publication DS 5, formerly STP 124), American Society for Testing Materials, Philadelphia.

Smith, G. V., 1969, An Evaluation of the Yield, Tensile, Creep, and Rupture Strengths of Wrought 304, 316, 321, and 347 Stainless Steels at Elevated Temperatures, ASTM Data Series DS5 S2 (Supplement to Publication DS5, formerly STP 124).

Wilkowski, G. M., 1984, "Margins of Safety Based on Circumferentially Cracked Depth Using the Net-Section Collapse Analysis," Proceedings of the CSNI Specialist Meeting on Leak-Before-Break in Nuclear Reactor Piping. NUREG/CR-0051, pp. 204-263.

Wilkowski, G. M., et al., 1989, Degraded Piping Program Phase II, NUREG/CR-4082, BMI-2120, Volume 8.

Yawaga, G., et al., 1984, "Stable and Unstable Growths of Circumferential Cracks in Type 304 Stainless Steel Pipes Under Tensile and Thermal Loading", Proceedings of the CSNI Specialist Meeting on Leak-Before-Break in Nuclear Reactor Piping, NUREG/CP-0051, pp. 56-125.

\section{NOTICE}

This paper was prepared as an account of work sponsored by an agency of the United States Government. Neither the United States Government nor any agency thereof, or any of their employees, makes any warranty, expressed or implied, or assumes any legal liability or responsibility for any third party's use, or the results of such use, of any information, apparatus, product or process disclosed in this report, or represents that its use by such third party would not infringe privately owned rights. The views expressed in this paper are not necessarily those of the U.S. Nuclear Regulatory Commission. 


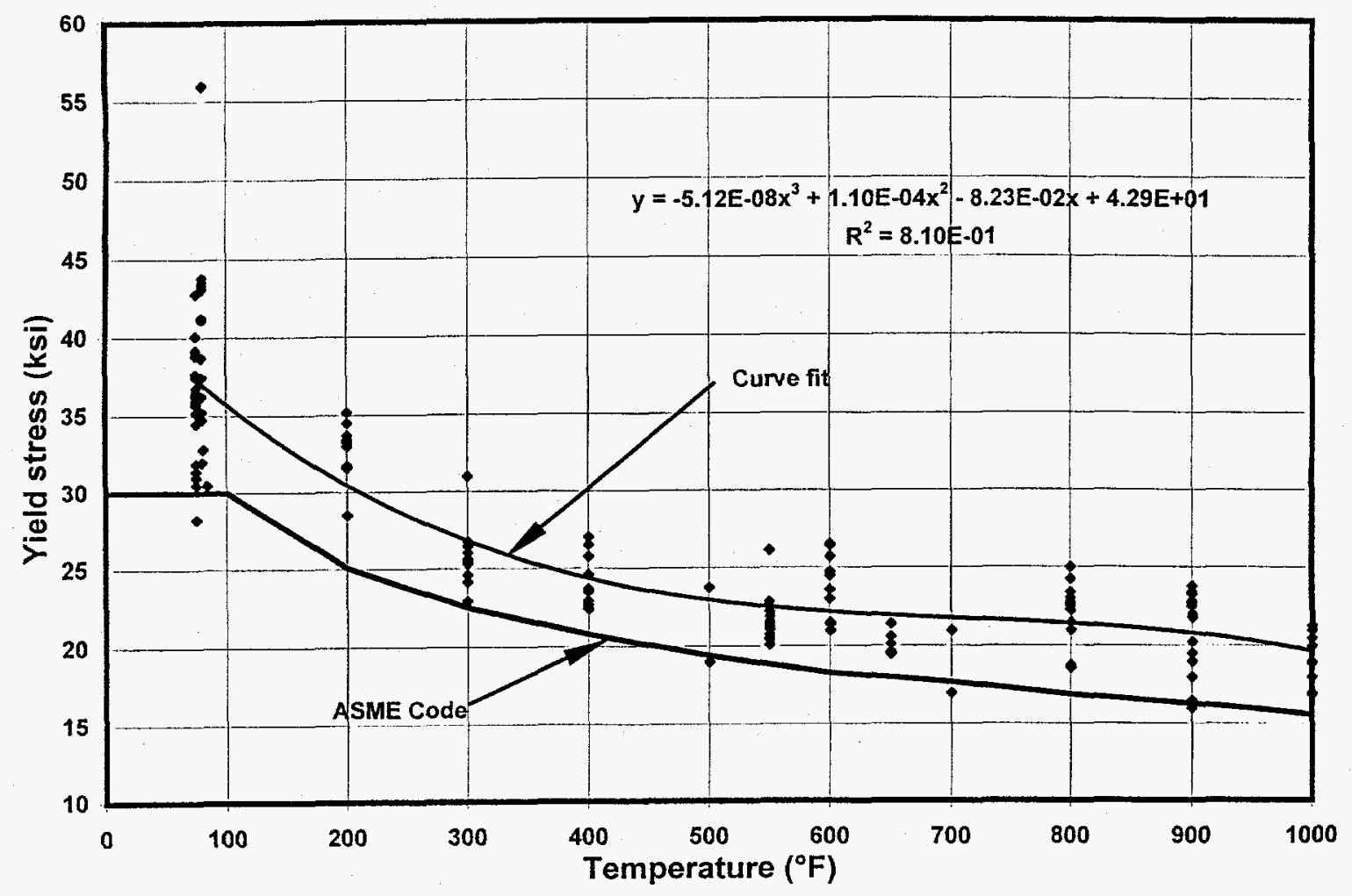

FIGURE 1. YIELD STRESS DATA FOR WROUGHT TYPE 304 STAINLESS STEEL PIPE.

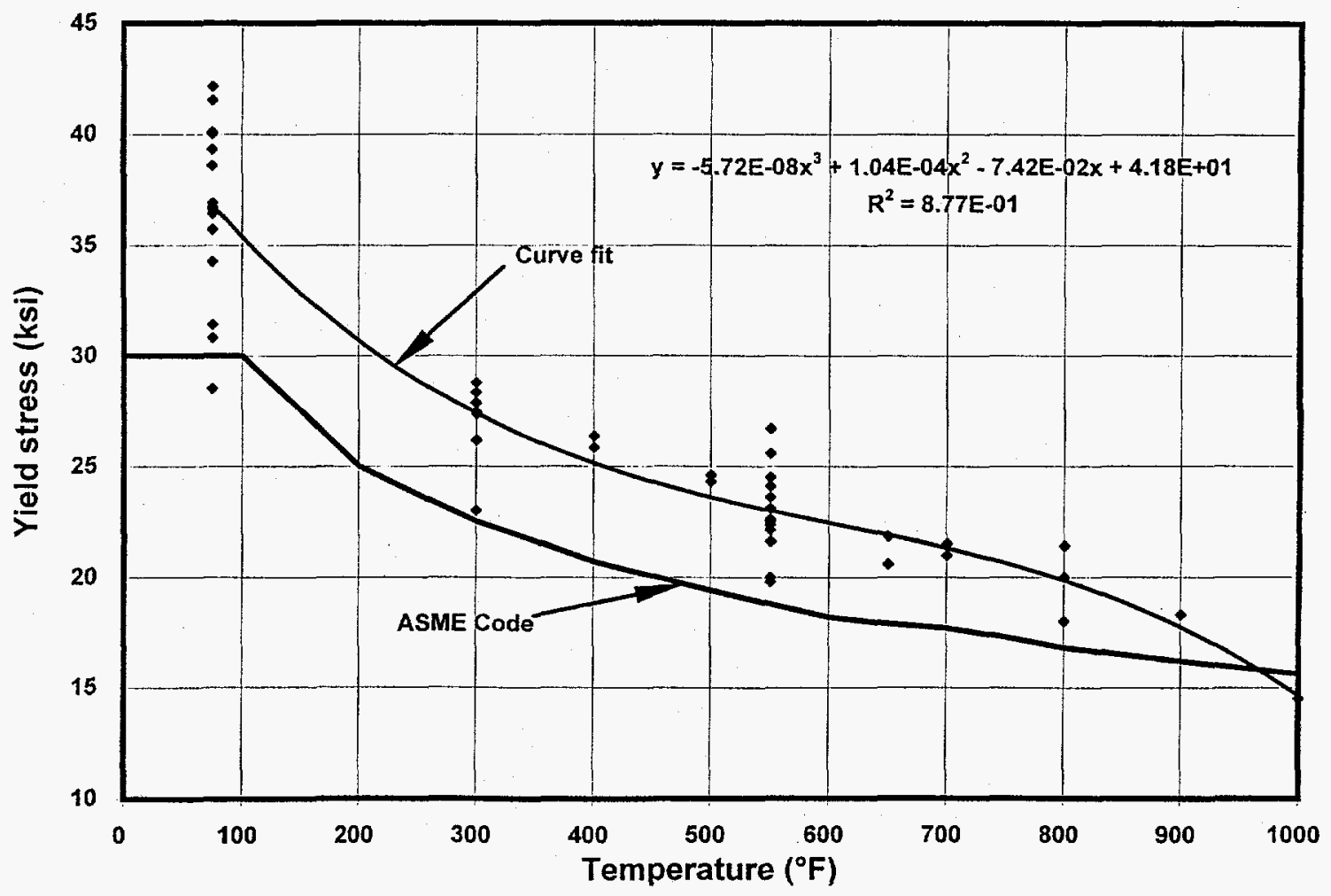

FIGURE 2. YIELD STRESS DATA FOR CAST TYPE 304 STAINLESS STEEL. 


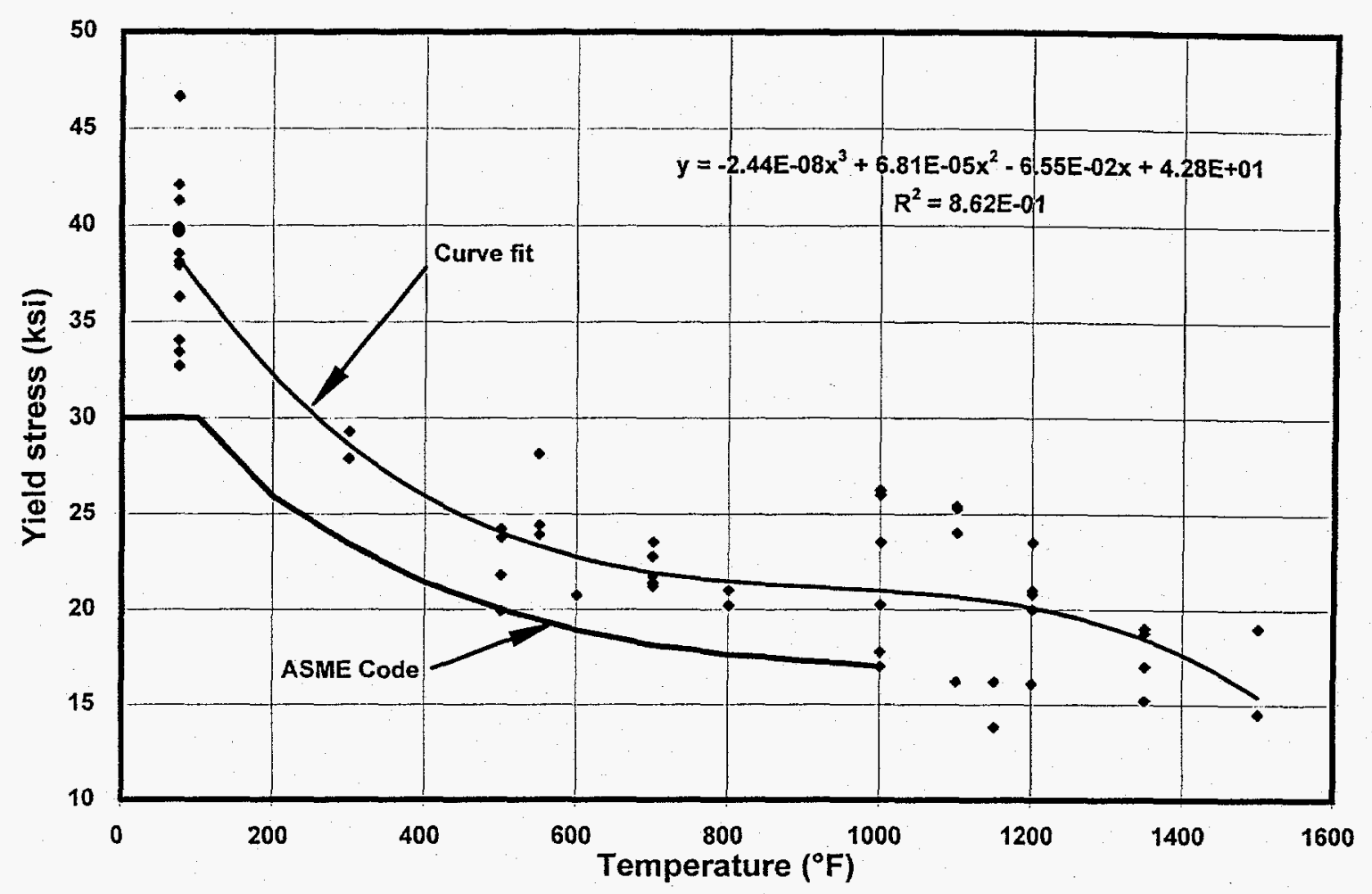

FIGURE 3. YIELD STRESS DATA FOR TYPE 316 STAINLESS STEEL.

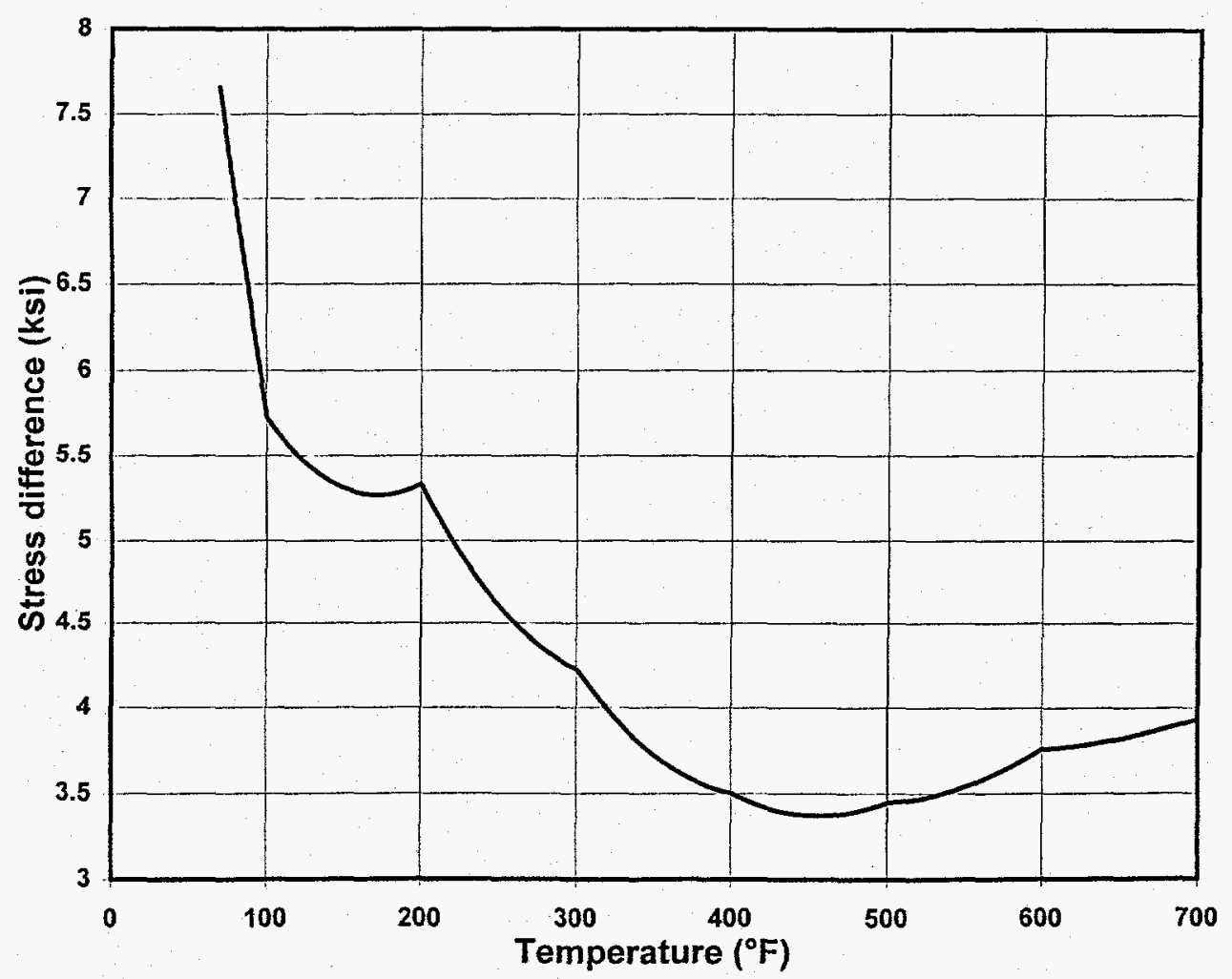

FIGURE 4. DIFFERENCE IN BEST-FIT CURVE AND ASME CODE YIELD STRESS VALUES FOR WROUGHT TYPE 304 STAINLESS STEEL PIPE. 


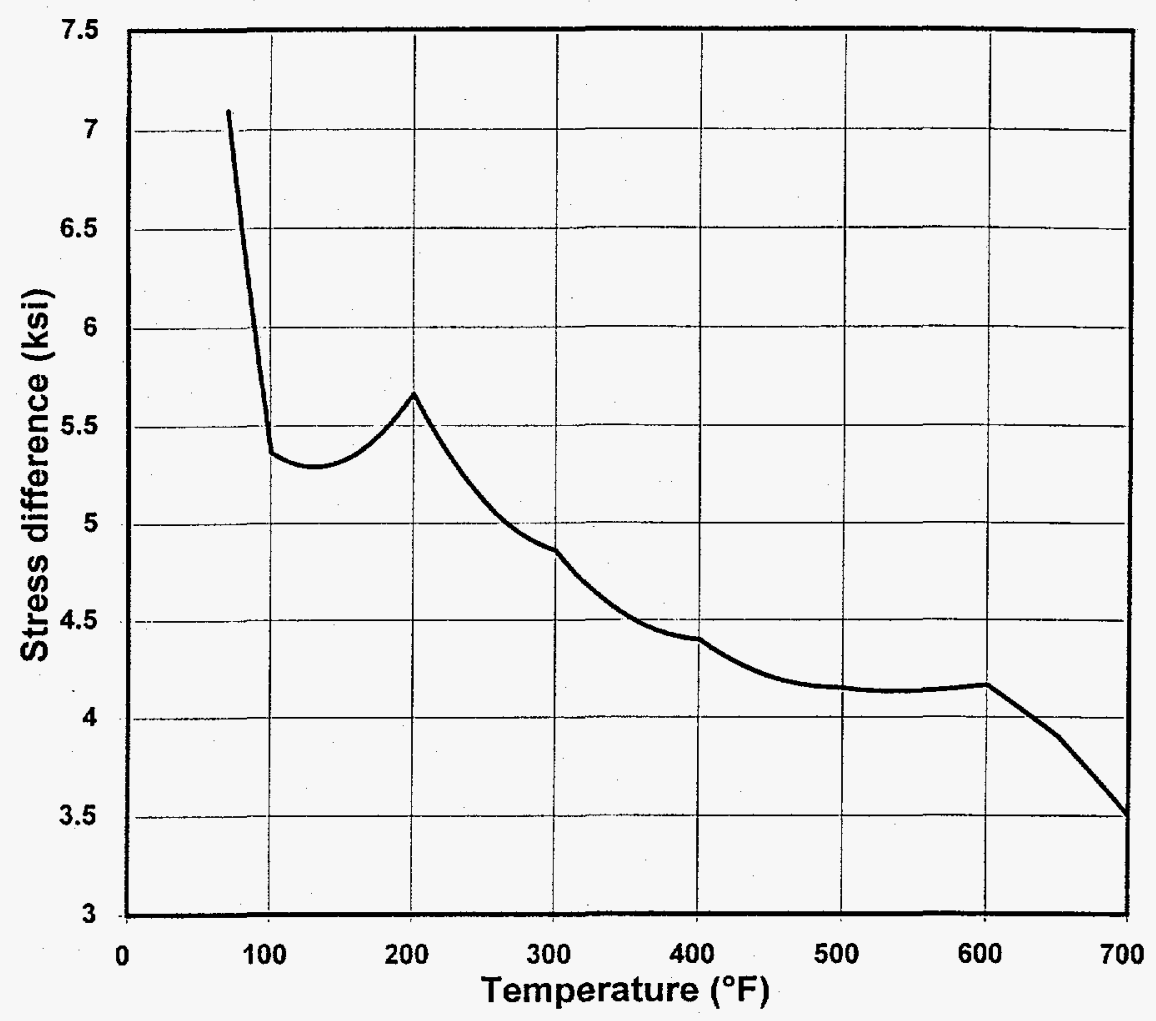

FIGURE 5. DIFFERENCE IN BEST-FIT CURVE AND ASME CODE YIELD STRESS VALUES FOR CAST TYPE 304 STAINLESS STEEL.

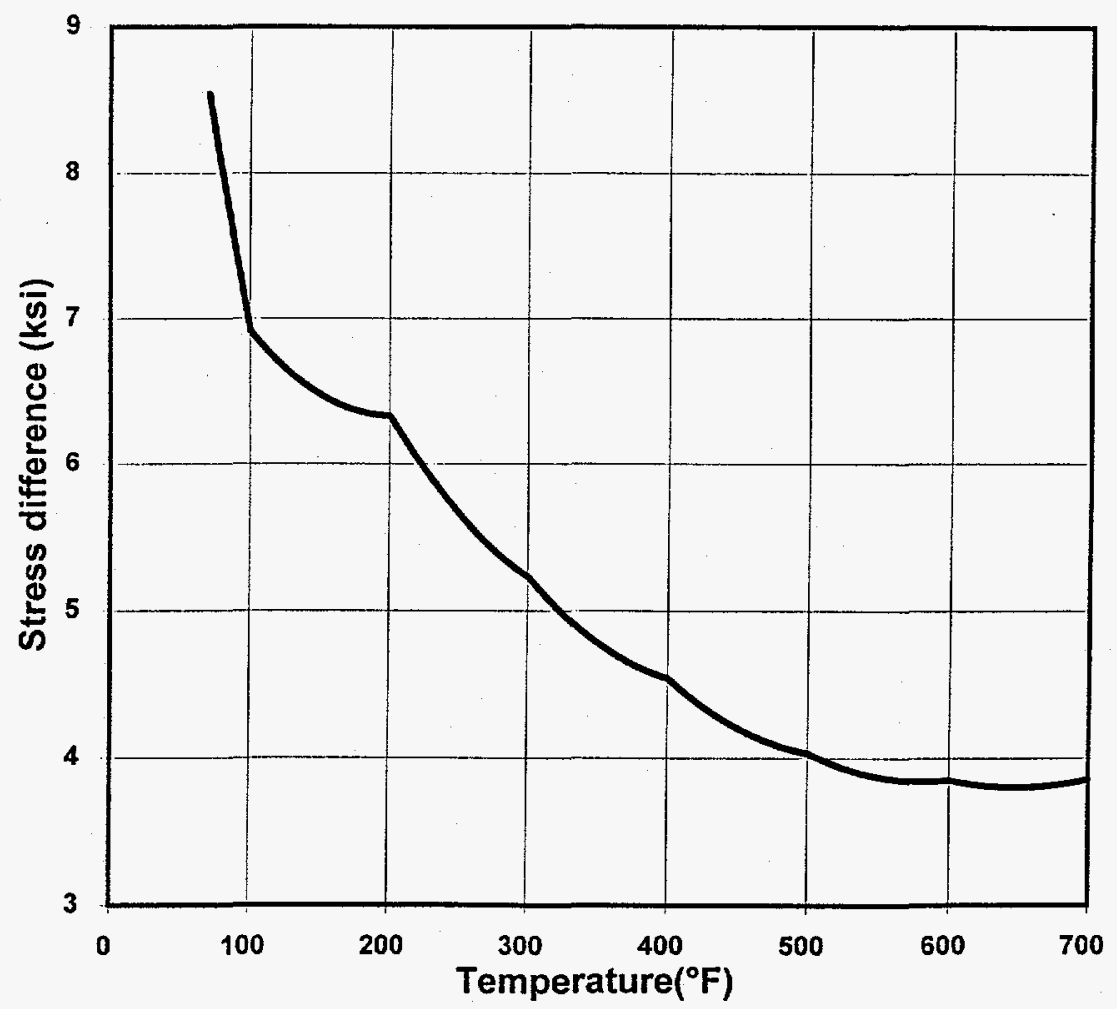

FIGURE 6. DIFFERENCE IN BEST-FIT CURVE AND ASME CODE YIELD STRESS VALUES FOR TYPE 316 STAINLESS STEEL. 


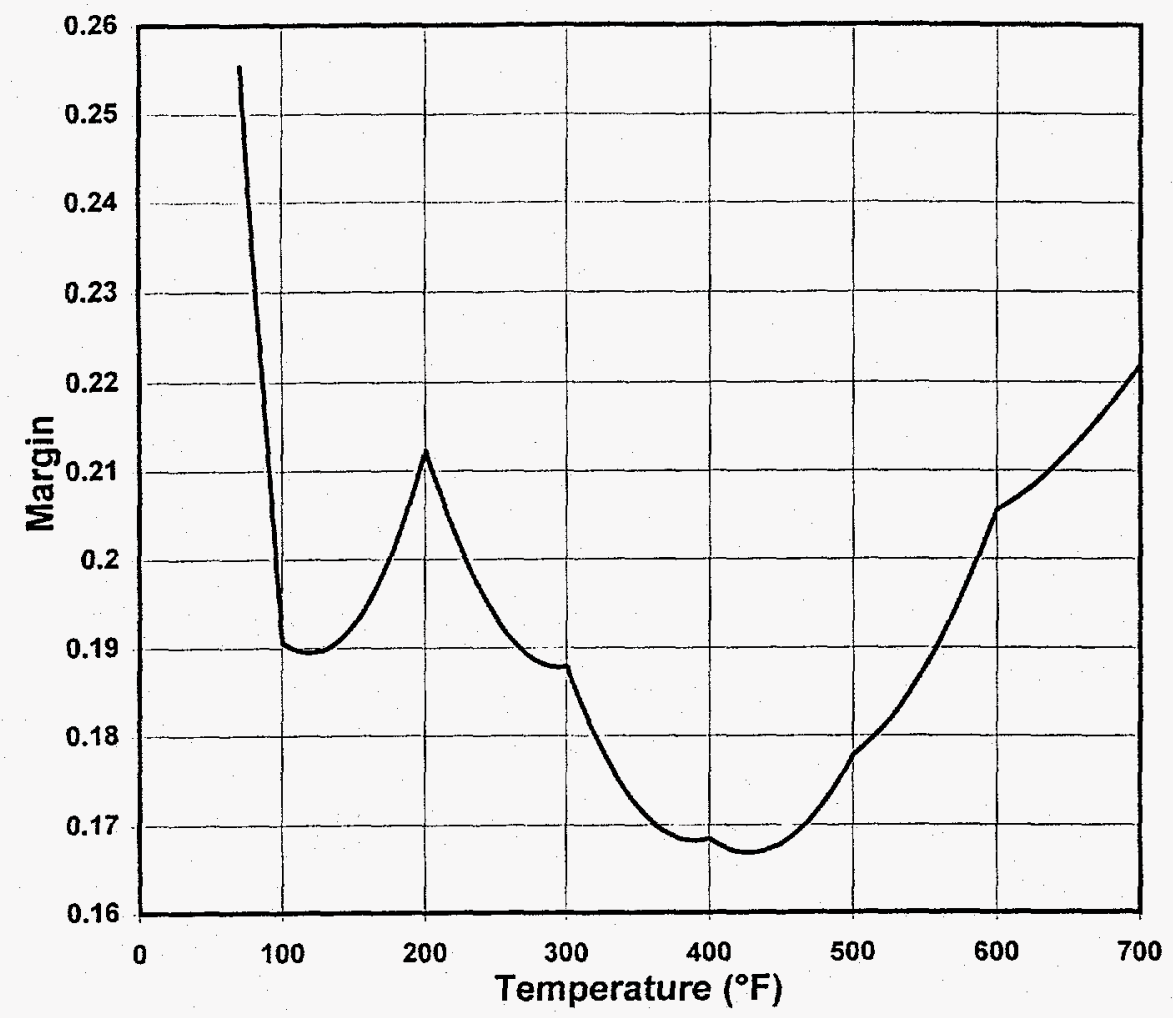

FIGURE 7. MARGIN OF ASME CODE TO BEST-FIT CURVE YIELD STRESS VALUES FOR WROUGHT TYPE 304 STAINLESS STEEL PIPE.

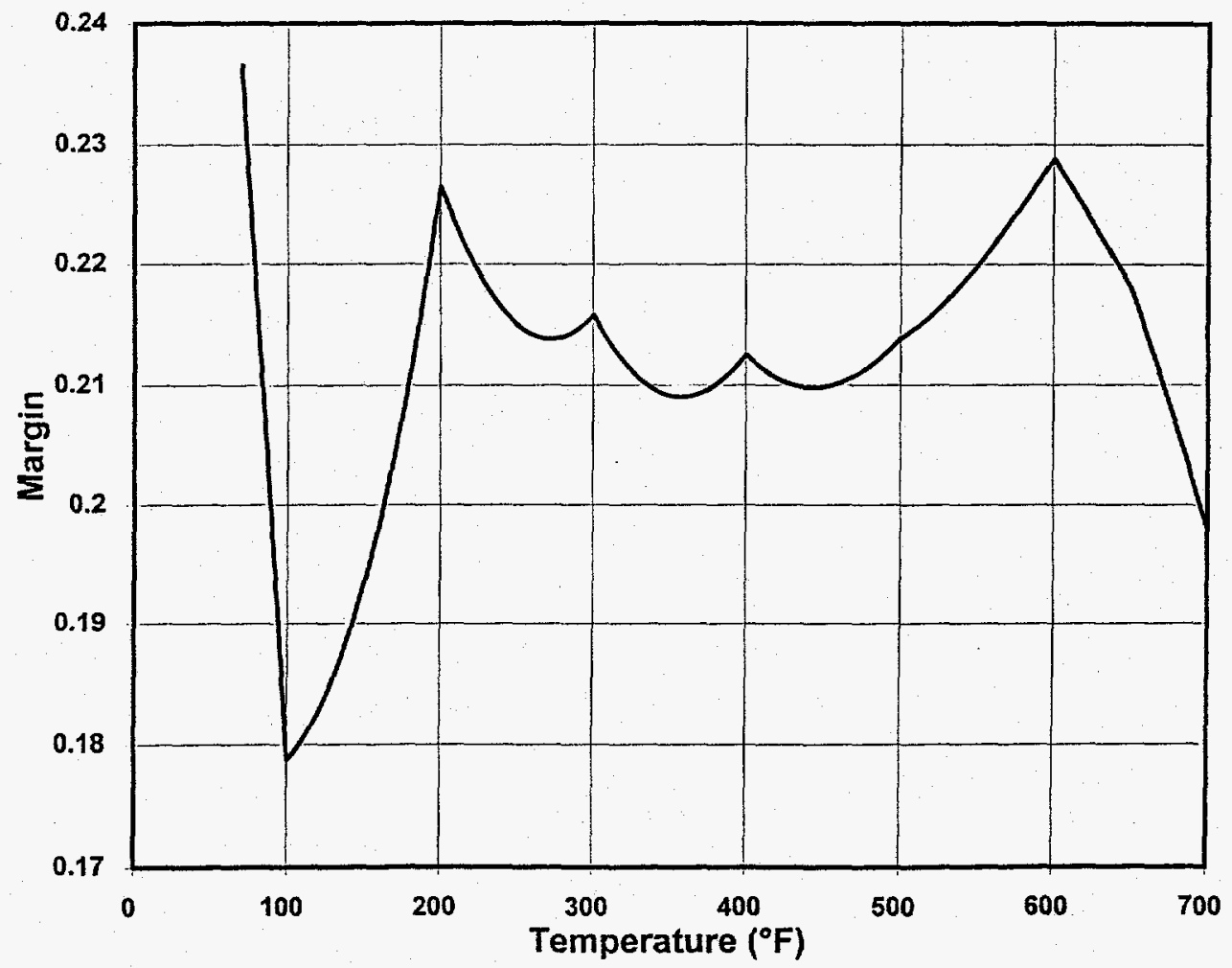

FIGURE 8. MARGIN OF ASME CODE TO BEST-FIT CURVE YIELD STRESS VALUES FOR CAST TYPE 304 STAINLESS STEEL.

A. G. Ware 


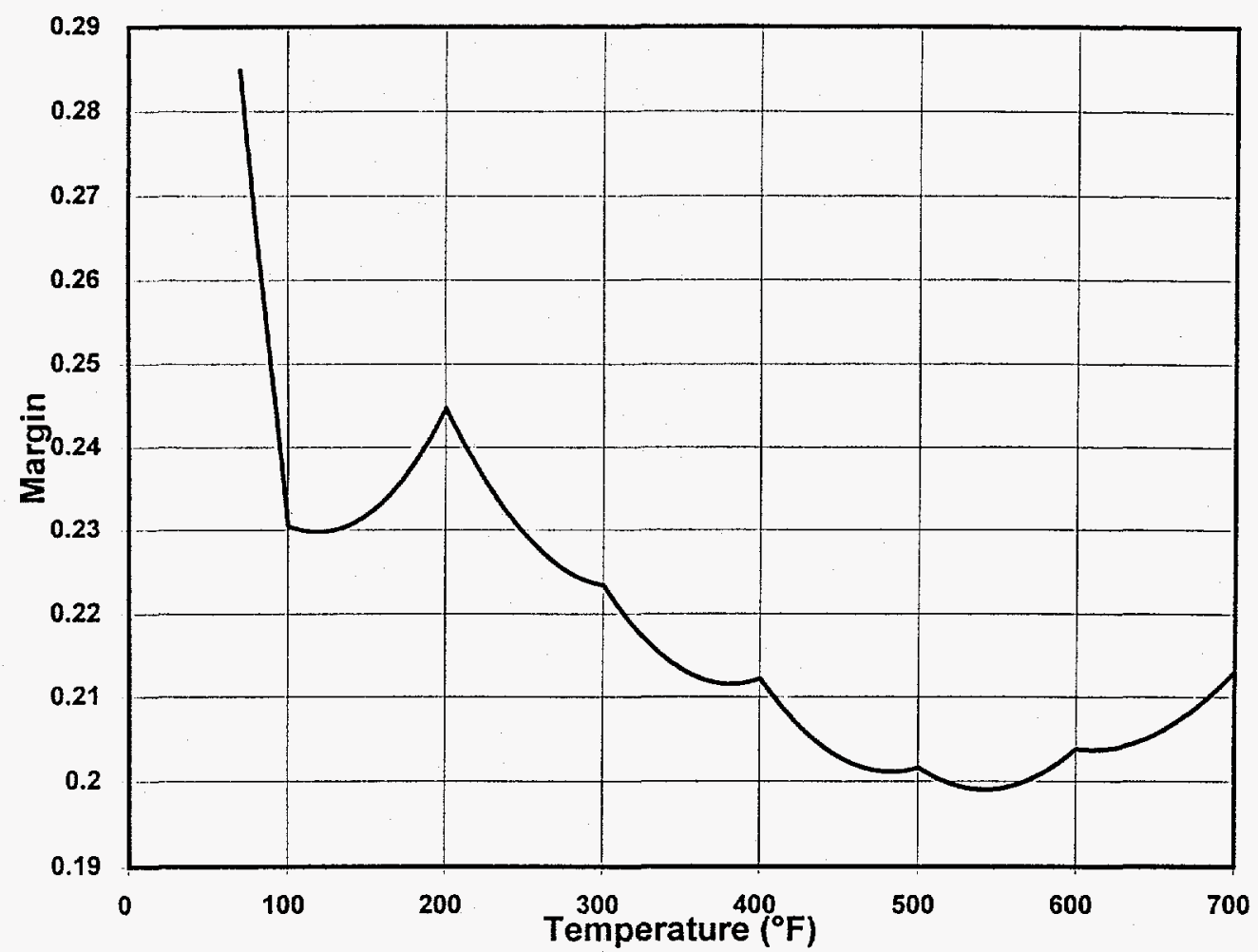

FIGURE 9. MARGIN OF ASME CODE TO BEST-FIT CURVE YIELD STRESS VALUES FOR TYPE 316 STAINLESS STEEL.

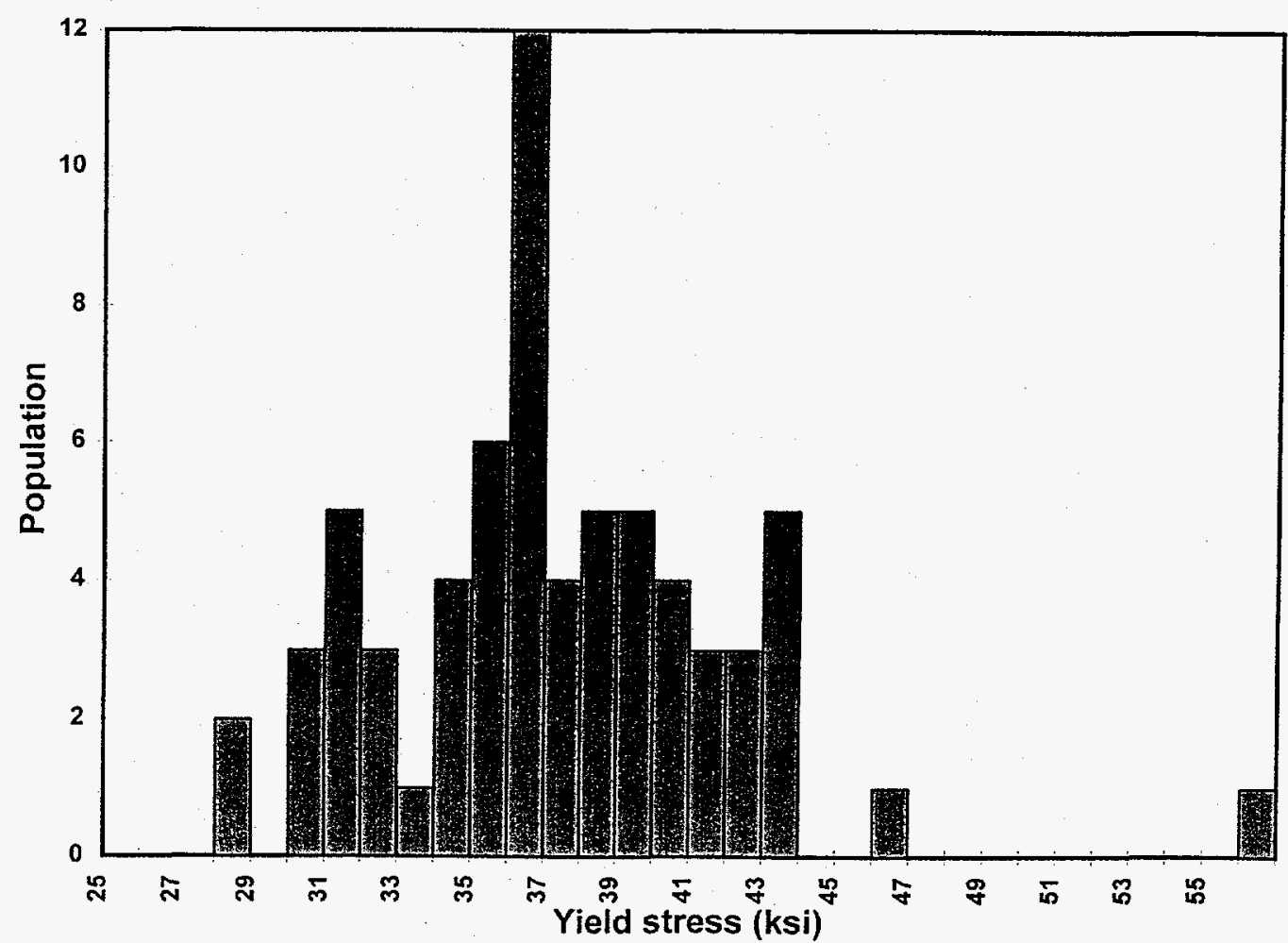

FIGURE 10. HISTOGRAM OF STAINLESS STEEL YIELD STRESS VALUES AT $70^{\circ} \mathrm{F}$. 


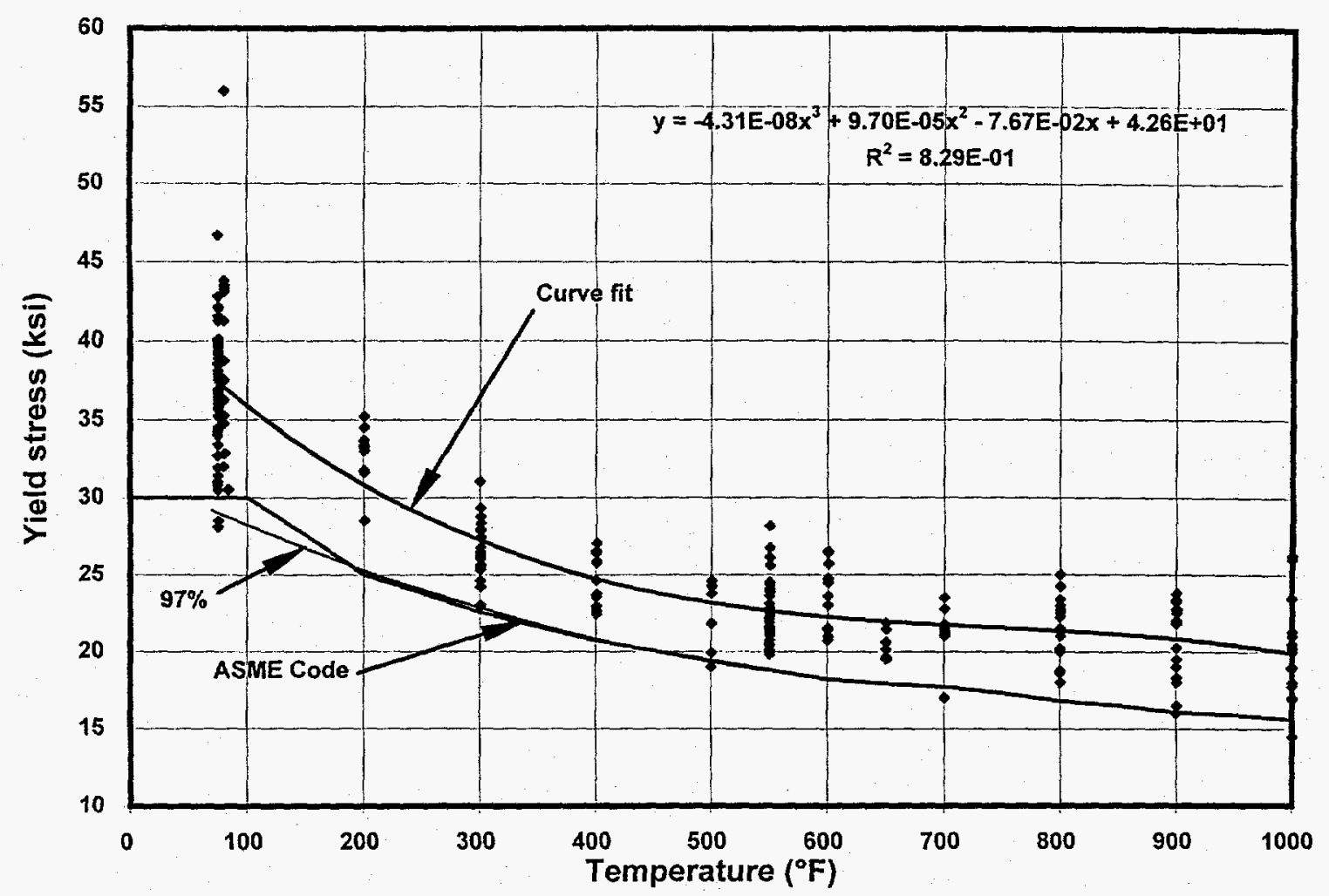

FIGURE 11. YIELD STRESS VALUES FOR TYPES 304 AND 316 STAINLESS STEELS.

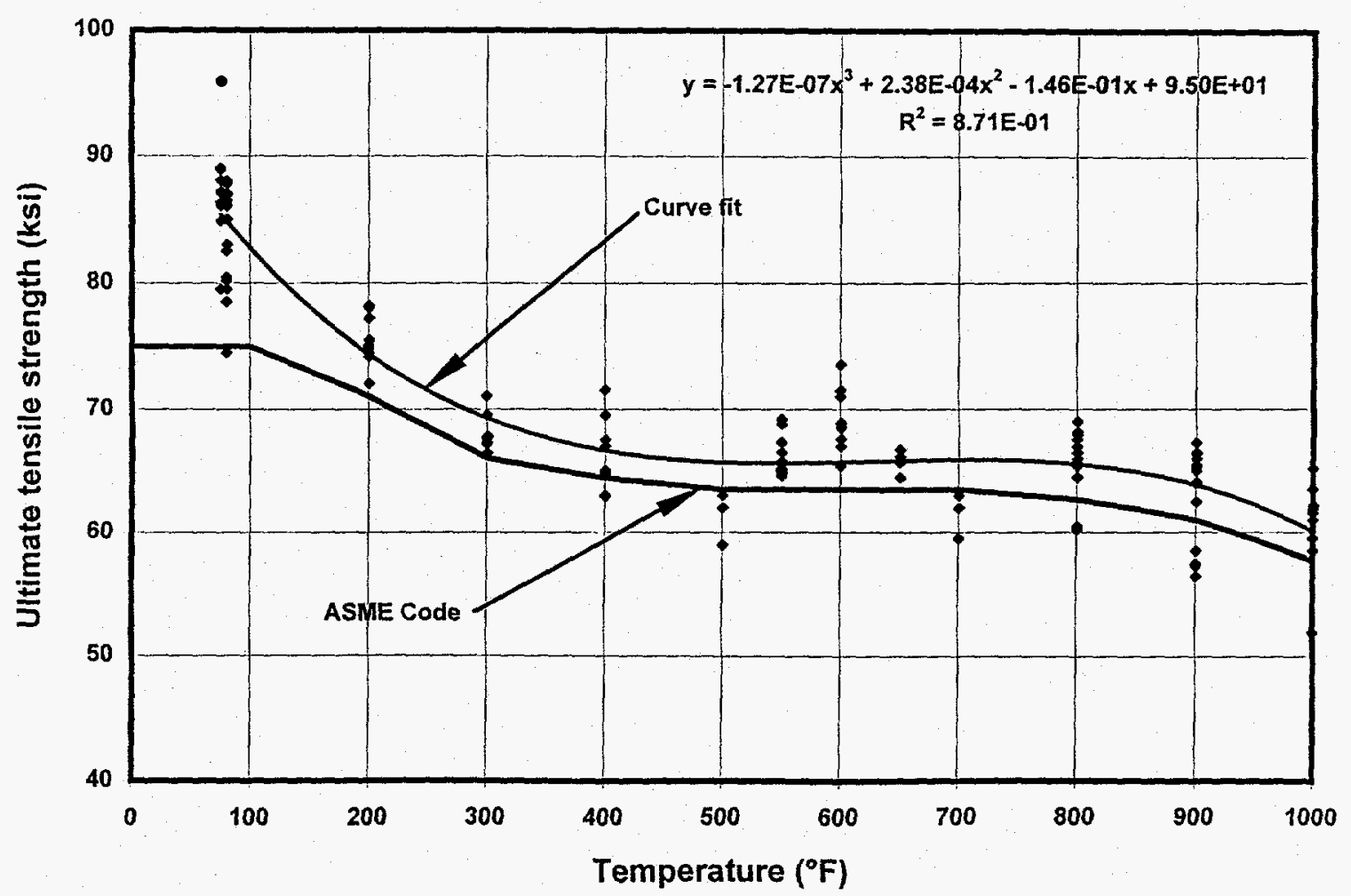

FIGURE 12. ULTIMATE TENSILE STRENGTH VALUES FOR WROUGHT TYPE 304 STAINLESS STEEL PIPE. 


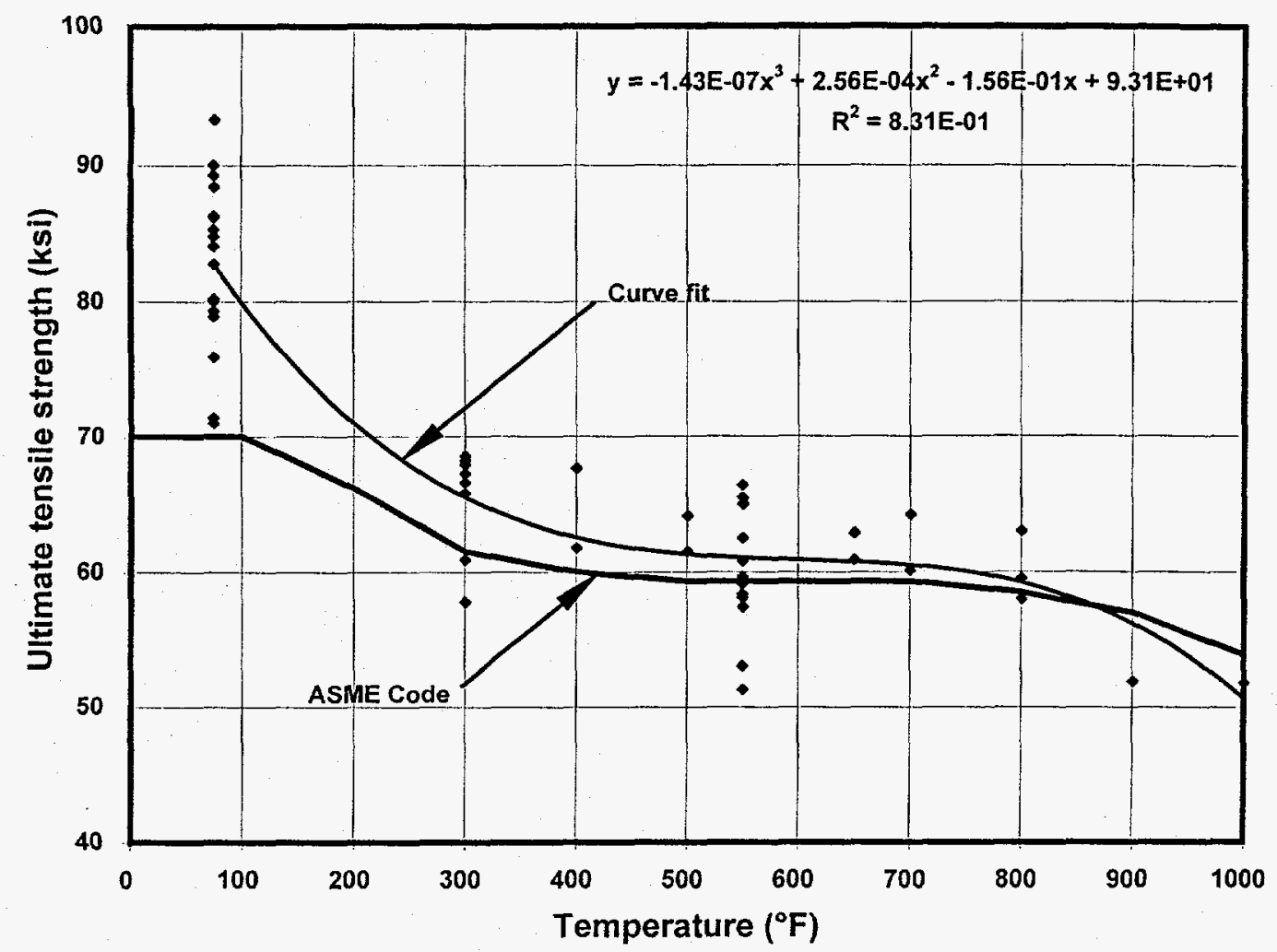

FIGURE 13. ULTIMATE TENSILE STRENGTH VALUES FOR CAST TYPE 304 STAINLESS STEEL.

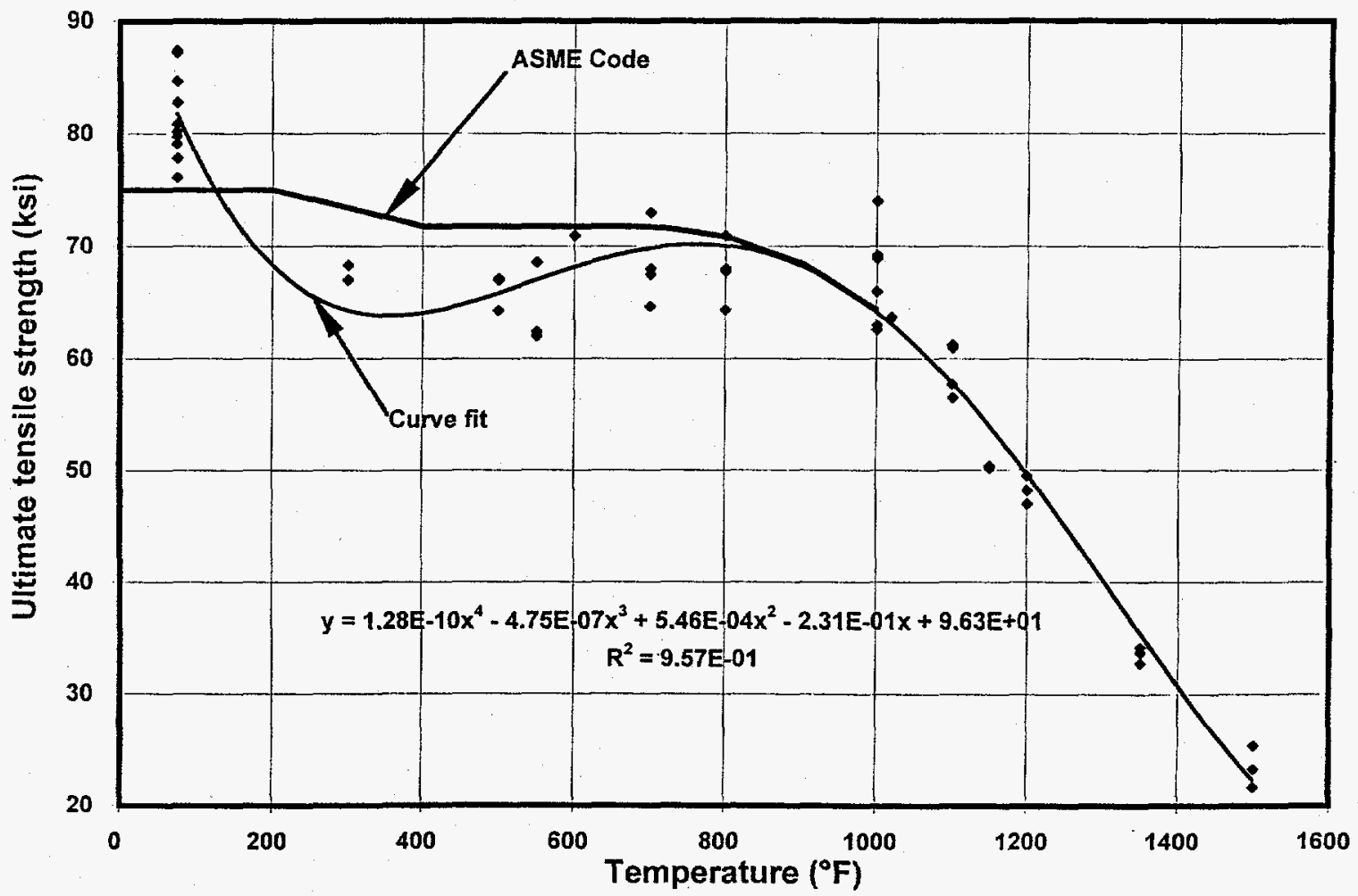

FIGURE 14. ULTIMATE TENSILE STRENGTH VALUES FOR TYPE 316 STAINLESS STEEL. 